\title{
Cloacogenic Adenocarcinoma of the Vulva: A Case Report and Review of the Literature
}

\author{
Merih TEPEOĞLU', Halit ÜNER², A.Nihan HABERAL', Özlem ÖZEN', Esra KUŞÇU³ \\ Department of Pathology, 'Başkent University School of Medicine, ANKARA, TURKEY, ${ }^{2}$ Hacettepe University School of Medicine, ANKARA, TURKEY \\ ${ }^{3}$ Department of Obstetrics and Gynecology, Başkent University School of Medicine, ANKARA, TURKEY
}

\begin{abstract}
Primary adenocarcinoma of the vulva, unrelated to the native glands of perineum is an extremely rare neoplasm. Despite awareness of this lesion for over 40 years, the origin is not beyond speculation. The most reasonable hypothesis is based on the remnants of cloacal differentiation during early days of life. Here we report the case of a 60 -year-old patient with a vulvar mass, who underwent partial vulvectomy and bilateral regional lymph node dissection. The tumor was composed of papillary and complex glandular structures and exhibited diffuse positivity for cytokeratin 20 and polyclonal CEA, CDX2, and focal positivity with cytokeratin 7. Unlike the indolent behavior of this malignant neoplasm according to the literature, we found two metastatic inguinal lymph nodes. She did not receive adjuvant therapy and is still alive, free of disease 38 months after surgery. We present different aspects of vulvar adenocarcinomas with a case report.
\end{abstract}

Key Words: Vulvar neoplasms, Adenocarcinoma, Cloacogenic, Metastasis

\section{INTRODUCTION}

Malignant tumors of vulva make up about \%4 of all gynecologic cancers and squamous cell carcinoma comprise $95 \%$ of them. Primary adenocarcinomas of the vulva are relatively rare and mostly originate from Bartholin's glands $(1,2)$. Colonic type adenocarcinoma is an extremely rare variant of vulvar adenocarcinoma and few cases have been reported since 1969 (3). The origin of these tumors is still controversial. It is suggested that they arise from cloacal remnants. Novak and Woodruff (2) proposed that misplaced cloacal remnants could be seen within the vulvar vestibule and the hypothesis that such misplaced remnants may undergo malignant transformation into an adenocarcinoma of the colonic type was suggested later by Tiltman and Knutzen (4). In the present study, we report a case of cloacogenic adenocarcinoma of vulva and we also discuss the pertinent published reports.

\section{CASE REPORT}

A post menopausal 60-year-old woman had a 9-month history of vulvar discomfort and bleeding. She had unremarkable medical history. Physical examination revealed a solitary, red, $2 \mathrm{~cm}$ in diameter tumor in the left labium minus, close to the urethral meatus. No other visible lesions of the vulva, vagina or perineum were found. The uterus was small and adnexial structures were not palpable. Shaving biopsy of the vulvar tumor

(Turk Patoloji Derg 2018, 34:255-258)

Received : 23.02.2016 Accepted : 12.04.2016 showed an adenocarcinoma of colonic type. Postoperative mammography, colonoscopy and PET scan findings were negative for a primary neoplasm. The subsequent operation was partial vulvectomy and dissection of bilateral superficial inguinal lymph nodes.

Resection material consisted of a minor labial fold and adjacent tissues measuring $4.5 \times 2.8 \times 1.5 \mathrm{~cm}$, with $2 \mathrm{~cm}$ ulcerated nodular reddish lesion that microscopically revealed a papillary tumor, reminiscent of a colonic adenocarcinoma. The neoplastic epithelium was in continuity with the surface epidermis (Figure 1). The tumor was composed of papillary and complex glandular structures lined bylarge columnar cells with hyperchromatic nuclei. Many cells were containing intracytoplasmic mucin and rare goblet cells were seen (Figure 2). The depth of invasion was measured as $0.8 \mathrm{~cm}$. Lateral and deep margins were free of tumor. Intracytoplasmic mucin was demonstrated with staining for Alcian blue histochemistry. Immunohistochemical analysis exhibited diffuse positivity for cytokeratin 20, polyclonal CEA and CDX2 (Figure 3). Only focal positivity was seen for cytokeratin 7 . No immunoreactivity was observed for WT-1 and GCDFP-15. Two of the 23 regional lymph nodes were metastatic with the tumor. The size of the metastatic focus was $15 \mathrm{~mm}$ in one of the positive lymph node and $2 \mathrm{~mm}$ in the other one. She did not receive adjuvant therapy. She is still alive and free of disease 38 months after surgery.

Correspondence:Merih TEPEOĞLU

Başkent Üniversitesi Tip Fakültesi, Patoloji Anabilim Dalı,

ANKARA, TURKEY

E-mail: merihdemirel@yahoo.com.tr Phone: +90 5058835126 


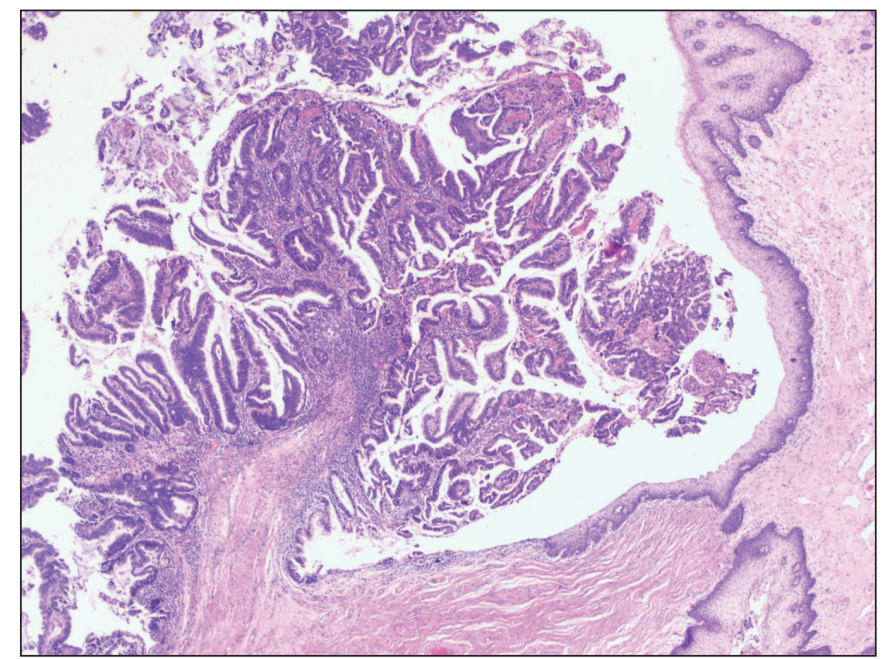

Figure 1: Adenocarcinoma arising in direct continuity with surface epidermis (H\&E; $\mathrm{x} 20)$.

\section{DISCUSSION}

Primary adenocarcinomas of the vulva are rare tumors while colonic types of these are exceptional (1-4). To the best of our knowledge, this is the ninth case ever published (4-10). Vulvar adenocarcinomas commonly originate from Bartholin's, sweat or vestibular glands or are more commonly derived from other systems; i.e. metastasis (8-11). It is postulated that the vestibular portion of vulva is derived from cloacal tissue that contains sigmoid colon and rectum of the hindgut $(7,8)$. This tissue retains the ability to undergo malignant transformation with differentiation into an adenocarcinoma similar to a primary adenocarcinoma of colon $(3,6)$. The histopathological and immunohistochemical features of these tumors are similar to those of a large intestinal adenocarcinoma. The possibility of metastasis, especially from the large intestine, must be ruled out by clinical work-up and also PET scan. The treatment of these tumors is radical vulvectomy or wide local excision with bilateral lymph node dissection. The clinical behavior is considered to be of indolent nature after surgery (5-8).

Similar lesions can also be seen in vagina (12). Although their origin is still the subject of speculation, the most commonly accepted notion is derivation from cloacal remnants, like vulvar lesions (12). These lesions can occur anywhere in the vagina but are most common in the lower posterior vagina (12). Exclusion of a metastasis to the vagina should also be undertaken before diagnosing a primary vaginal-type adenocarcinoma.

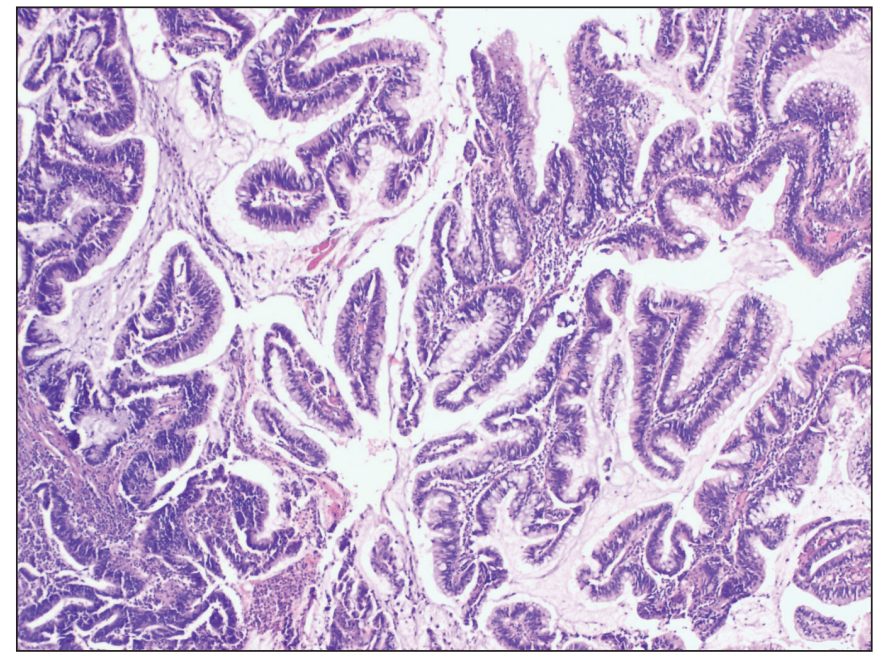

Figure 2: Higher magnification shows complex glandular structures lined by large columnar cells with hyperchromatic nuclei and containing intracytoplasmic mucin (H\&E; x40).

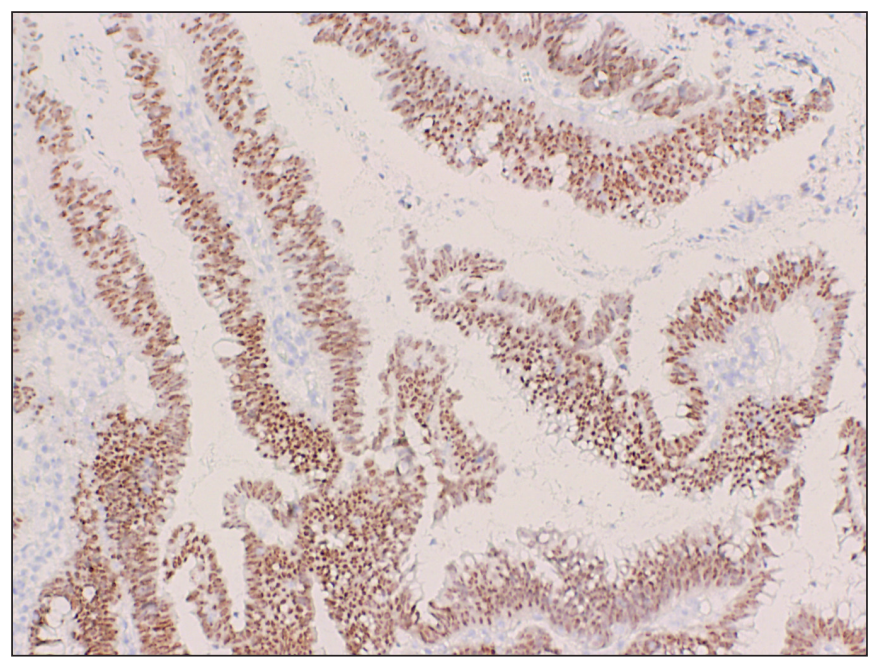

Figure 3: Tumor cells show intranuclear staining for CDX2 antigen by immunohistochemistry (CDX2; x40).

In our case, probable metastasis was excluded by PET scan and complete clinical workup. Detailed evaluation of the gastrointestinal tract, breast and lung showed no evidence of a primary tumor. Bartholin's or other gland adenocarcinoma was ruled out by the location of far from vestibule, close to the urethral meatus, and the absence of any native Bartholin's gland adjacent to the tumor. The final diagnosis was therefore cloacogenic mucinous adenocarcinoma with regard to the histopathological and immunohistochemical findings. Strong cytokeratin 20 and weak cytokeratin 7 expression favoured the diagnosis. Additional polyclonal CEA and CDX2 positivity was consistent with the diagnosis of colonic type adenocarcinoma as reported in the previous cases $(7,11)$. 
Table I: Clinical features and outcome of 10 patients

\begin{tabular}{|c|c|c|c|c|c|c|c|}
\hline Author & Year & Age & Location & Diagnosis & Treatment & $\begin{array}{l}\text { Lymph node } \\
\text { metastasis }\end{array}$ & Prognosis \\
\hline Tiltman et al (4) & 1978 & 50 & Periurethral & Adenocarcinoma & $\begin{array}{c}\text { Modified radical } \\
\text { vulvectomy + bilateral } \\
\text { inguinal lymph node } \\
\text { dissection }\end{array}$ & Positive $(+1)$ & Not available \\
\hline Lee et al (5) & 1990 & 79 & Not available & Adenocarcinoma & Not available & Negative & $\begin{array}{l}\text { Disease-free } \\
\text { (18 months) }\end{array}$ \\
\hline Kennedy et al (6) & 1993 & 54 & Left posterior & Adenocarcinoma & Radical vulvectomy & Negative & $\begin{array}{l}\text { Disease-free } \\
\text { (120 months) }\end{array}$ \\
\hline Kennedy et al (6) & 1993 & 63 & $\begin{array}{c}\text { Posterior } \\
\text { fourchette }\end{array}$ & Adenocarcinoma & Wide local excision & Negative & $\begin{array}{l}\text { Disease-free } \\
\text { (48 months) }\end{array}$ \\
\hline Willen et al (7) & 1999 & 57 & $\begin{array}{l}\text { Posterior part } \\
\text { of vestibulum }\end{array}$ & Adenocarcinoma & Local excision & Negative & $\begin{array}{l}\text { Disease-free } \\
\text { (26 months) }\end{array}$ \\
\hline Zaidi et al (8) & 2001 & 43 & $\begin{array}{l}\text { Posterior } \\
\text { fourchette }\end{array}$ & Adenocarcinoma & $\begin{array}{c}\text { Modified radical } \\
\text { vulvectomy + bilateral } \\
\text { inguinal lymph node } \\
\text { dissection }\end{array}$ & Negative & $\begin{array}{l}\text { Disease-free } \\
\text { (18 months) }\end{array}$ \\
\hline Liu et al (9) & 2003 & 49 & $\begin{array}{l}\text { Left labium } \\
\text { majus }\end{array}$ & Adenocarcinoma & $\begin{array}{c}\text { Wide local excision }+ \\
\text { bilateral inguinal lymph } \\
\text { node dissection }\end{array}$ & Negative & $\begin{array}{l}\text { Disease-free } \\
\text { (24 months) }\end{array}$ \\
\hline Dube et al (10) & 2004 & 58 & $\begin{array}{l}\text { Right labium } \\
\text { majus }\end{array}$ & Adenocarcinoma & $\begin{array}{c}\text { Radical hemivulvectomy } \\
+ \text { ipsilateral lymph } \\
\text { node dissection }+ \\
\text { laparoscopic right SPO }\end{array}$ & Negative & $\begin{array}{l}\text { Disease-free } \\
\text { (16 months) }\end{array}$ \\
\hline Our case & 2016 & 60 & $\begin{array}{l}\text { Left labium } \\
\text { minus }\end{array}$ & Adenocarcinoma & $\begin{array}{l}\text { Partial vulvactomy }+ \\
\text { bilateral inguinal lymph } \\
\text { node dissection }\end{array}$ & Positive $(+2)$ & $\begin{array}{l}\text { Disease-free } \\
\text { (38 months) }\end{array}$ \\
\hline
\end{tabular}

The published reports on tumors developing from cloacogenic remnants within the vulva consist mainly of single case reports. Tiltman and Knutzen (4) reported the first case of cloacogenic adenocarcinoma and they mentioned that the cell origin of this adenocarcinoma was a misplaced cloacal remnant. After Tiltman, Lee et al. (5) reported a case of multicentric cloacogenic carcinoma of the perianal skin and vulva. Kennedy and Majmudar (6) published two cases of primary adenocarcinomas of vulva and repeated that the possible origin was cloacal structures. Furthermore, Willen et al., Zaidi and Conner, Liu et al. and Dube et al. presented case reports of primary vulvar cloacogenic adenocarcinomas (7-10). Cloacogenic-derived adenocarcinomas are most often seen in postmenopausal women, but premenopausal cases have been reported (8). The mean age of the patients reported was 51 years (range between 38-63 years). In the majority of these cases, tumors ranged in size from 1 to $2 \mathrm{~cm}$ largest diameter. In all the cases described, the clinical behavior of this rare tumor was quite indolent and overall survival was excellent after radical vulvectomy or wide total excision. Bilateral inguinal lymph node dissection has been performed in four of the reported cases $(4,8-10)$ and only one showed ipsilateral metastasis (4). In our case, metastatic adenocarcinoma was found in two of bilateral inguinal lymph nodes sampled. Therefore, in our opinion, ipsilateral or bilateral inguinal lymph node dissection is indicated. The summary of clinical features and management of these patients can be seen in Table I.

In conclusion, knowledge of cloacogenic vulvar adenocarcinomas is very limited due to the small number of cases. A cloacogenic origin should be considered in intestinal-like or mucinous neoplasms. Nodal metastasis should always be kept in mind both in clinical and pathological examination. 


\section{CONFLICT OF INTEREST}

The authors declared no conflict of interest

\section{REFERENCES}

1. Wilkinson EJ: Premalignant and malignant tumors of the vulva In: Kurman RJ, editor. Blaustein's pathology of the female genital tract. 6th ed. New York: Springer; 2011. 55-103.

2. Novak ER, Woodruff JD. Gynecologic and obstetric pathology with clinical and endocrine relations. 7th ed. Philadelphia: Saunders; 1974. 26.

3. Stern BD, Kaplan L. Multicentric foci of carcinomas arising in structures of cloacal origin. Am J Obstet Gynecol. 1969; 104:25566.

4. Tiltman AJ, Knutzen VK. Primary adenocarcinoma of the vulva originating in misplaced cloacal tissue. Obstet Gynecol. 1978;51:30-3.

5. Lee KC, Su WP, Muller SA. Multicentric cloacogenic carcinoma: Report of a case with anogenital pruritus at presentation. J Am Acad Dermatol. 1990;23:1005-8.

6. Kennedy JC, Majmudar B. Primary adenocarcinoma of the vulva, possibly cloacogenic. A report of two cases. J Reprod Med. 1993;38:113-6.
7. Willén R, Békássy Z, Carlén B, Bozoky B, Cajander S. Cloacogenic adenocarcinoma of the vulva. Gynecol Oncol. 1999;74:298-301.

8. Zaidi SN, Conner MG. Primary vulvar adenocarcinoma of cloacogenic origin. South Med J. 2001;94:744-6.

9. Liu SH, Ho CM, Huang SH, Shih BY, Lee FK. Cloacogenic adenocarcinoma of the vulva presenting as recurrent Bartholin's gland infection. J Formos Med Assoc. 2003;102:49-51.

10. Dubé V, Veilleux C, Plante M, Têtu B. Primary villoglandular adenocarcinoma of cloacogenic origin of the vulva. Hum Pathol. 2004;35:377-9.

11. Rodriguez A, Isaac MA, Hidalgo E, Márquez B, Nogales FF. Villoglandular adenocarcinoma of the vulva. Gynecol Oncol. 2001;83:409-11.

12. Staats PN, McCluggage WG, Clement PB, Young RH. Primary intestinal-type glandular lesions of the vagina: clinical, pathologic, and immunohistochemical features of 14 cases ranging from benign polyp to adenoma to adenocarcinoma. Am J Surg Pathol. 2014;38:593-603. 